\title{
Salinity influences body weight quantification in the scyphomedusa Aurelia aurita: important implications for body weight determination in gelatinous zooplankton
}

\author{
Andrew G. Hirst*, Cathy H. Lucas \\ ${ }^{1}$ Department of Oceanography, Southampton Oceanography Centre, Empress Dock, Southampton, SO14 3ZH, United Kingdom
}

\begin{abstract}
Comparisons are made between bell diameter:weights (wet, dry, ash-free dry, ash and elemental) relationships for the scyphomedusa Aurelia aurita (L.). There are significant differences in the relationships between bell diameter and dry, ash-free dry and ash weights at different salinities. with these weights increasing as the ambient salinity increases. These trends are attributable to differences in the quantity of both bound water (i.e. 'water of hydration') and ash content, both of which vary with the size of medusae. Dry, ash-free dry and ash weights change rapidly as the salinity of an individual's environment alters, and these changes are associated with changes in the individual's buoyancy. Unless salinity effects are appropriately considered, significant errors may arise in the quantification of the biomass, production, and other weight-dependent measurements of $A$. aurita. Similar errors arise in other gelatinous organisms, and studies of such groups must make allowances for these effects.
\end{abstract}

KEY WORDS: Aurelia aurita - Wet weight - Dry weight - Ash-free dry weight - Ash weight - Salinity Water of hydration

\section{INTRODUCTION}

Gelatinous zooplankton is the term used to describe a heterogenous group of organisms which have a high body water content [dry weight (DW) typically 3.5 to $30 \%$ of wet weight (WW)] and, therefore, a large size in relation to their organic content. Included in this definition are the truly gelatinous forms, such as the ctenophores, medusae and siphonophores ( $D W \approx 3.5$ to $5 \%$ WW; Larson 1986), as well as the semi-gelatinous forms which include chaetognaths, heteropods, pteropods and thaliaceans ( $D W \approx 3.5$ to $30 \% W_{W}$ i Larson 1986). The present examination concentrates on the scyphomedusa Aurelia aurita, a truly gelatinous form, which is a cosmopolitan neritic species with a worldwide distribution (Kramp 1961). The population

\footnotetext{
- Present address: George Deacon Division, Southampton Oceanography Centre, Empress Dock, Southampton, SO14 3ZH, UK.E-mail: a.hirst@soc.soton.ac.uk
}

dynamics of this species has been studied extensively from a variety of neritic habitats (Yasuda 1971, Hamner \& Jenssen 1974, Möller 1980, Lucas \& Williams 1994, Olesen et al. 1994). It is one of the most studied gelatinous species because of its relative accessibility, high abundance, size, ease of handling, and presumably its importance.

Gelatinous and semi-gelatinous species have often been shown to be of fundamental importance as predators and transformers of matter in pelagic systems (Alldredge 1984). Two commonly applied measures of biomass, production, and material fluxes in the marine environment are dry weight and ash-free dry weight (AFDW) (e.g. Reeve \& Baker 1975, Huntley \& Hobson 1978, García 1990, Olesen et al. 1994, Lucas \& Williams $1995)$. Both these weight types are relatively easy to determine. Comparisons of standing stock and production in these units have also been made directly between trophic levels in marine systems, including comparisons between copepod crustaceans (prey) and 
medusae (predators) (e.g. Huntley \& Hobson 1978). Indeed, in the much cited review of the quantitative significance of gelatinous zooplankton, Alldredge (1984) made comparisons between the DW standing stock of the gelatinous predators with that of their prey. However, DW and AFDW are poor representatives of gelatinous biomass, particularly when compared directly to other non-gelatinous groups (Omori \& Ikeda 1984), with the former weight type being more misleading than the latter. Carbon weight (C) typically constitutes 30 to $60 \%$ of the DW of non-gelatinous zooplankton, whereas it may represent $<1$ to $15 \%$ of the DW of gelatinous zooplankton (Larson 1986). Nitrogen $(\mathrm{N})$, phosphorus $(\mathrm{P})$ and energy content $(\mathrm{J})$ of gelatinous tissue are also much lower than in non-gelatinous tissue. One example highlighting the inappropriateness of such comparisons is the DW gross growth efficiency (GGE) of $37 \%$ for Aurelia aurita fed with mixed food including copepods (Fraser 1969). This value has been compared with elemental growth efficiencies (e.g Conover 1979, Alldredge 1984, Olesen et al. 1994), yet they are not compatible. Indeed, the GGE value of Fraser (1969), when converted to carbon, gives a value of $4.6 \%$ (Hirst 1996). Further, flow of matter assessed using DW or AFDW may not even obey the axiom of ecology that production at higher trophic levels must be lower than at the lower trophic levels, as applies for energy (Odum 1971).

The reason for such elements as C, N and $P$ being such small percentages of DW and AFDW in gelatinous organisms may be the result of the presence of 'water of hydration' (Reeve \& Baker 1975, Larson 1986). Water of hydration is bound water which is not removed during the procedures typically applied in the determination of DW (freeze drying or oven drying at -50 to $70^{\circ} \mathrm{C}$ ). This water is, however, driven off during the ashing process (at $\sim 550^{\circ} \mathrm{C}$ ). Because AFDW is dependent upon correctly assessing DW, its measurement is also affected. The result of not removing bound water is a false increase in DW and AFDW values. For this reason it is common in studies of gelatinous organisms such as Aurelia aurita to convert from DW or AFDW to elemental values using ratios determined by other workers and in other areas (e.g. Möller 1979, van der Veer \& Oorthuysen 1985, Lucas \& Williams 1994, Olesen et al. 1994, Lucas 1996). Inherent in such conversions is the assumption that the ratios of elements to DW or AFDW do not vary dramatically or in a consistent way. We question this common assumption in the following investigation.

Hyman $(1938,1940,1943)$ was possibly the first to appreciate that the water content of medusae varies with ambient salinity. Vinogradov's (1953) review of the elementary composition of coelenterates also acknowledges the effect of salinity on weight, noting that '... Aurelia aurita from the more dilute waters of the Baltic is seen to be richer in water... than in the same species from normal oceanic water' More recently, Larson (1985) found in laboratory acclimation studies on the hydromedusa Aequorea victoria that dry weight as a percentage of wet weight (DW\%WW) increased with increasing salinities. Schneider (1988) noted that DW may be a poor indicator of biomass in coelenterates because of changes with ambient salinity. Apart from a few, very limited accounts of the influence of salinity on gelatinous biomass, this topic has apparently gone largely unconsidered. In this investigation, using the combination of a literature survey and experiments, for the first time we examine comprehensively changes in the relationships between weight [WW, DW, AFDW and AW (ash weight)] and bell diameter in Aurelia aurita as a function of ambient environmental salinity. Our results demonstrate large and important effects for this species, these effects probably being significant for weight quantification in other gelatinous zooplankton found in varying salinities.

\section{MATERIALS AND METHOD}

Compilation and comparisons. Bell diameter:weight relationships for Aurelia aurita medusae available in the published literature and from previously unpublished work were compiled. Table 1 lists all the equations found describing body weight expressed as wet weight (WW), dry weight (DW), ash-free dry weight (AFDW) and ash weight (AW), and the elemental terms $C, N$ and $P$, as a function of the bell diameter. When possible all equations were re-arranged into the standard form:

$$
W=a L^{b}
$$

$L$ is the bell diameter (mm) and $W$ is the weight $(\mathrm{g})$. When equations were not compatible to this form they were rearranged to their simplest form. The salinity of water from which the individuals were collected or maintained is also given when available, as are the bell diameter limits of the regressions. When a range of salinities was given the mid-point was usedi in all cases, ranges were $\leq 2 \%$, so estimates from the midpoints cannot be more than $1 \%$ in error. Although all equations found in the literature are quoted, only those in which the limits of the regression and salinity of collection were available were used in the analysis for comparisons of WW, DW, AFDW and AW, these are indicated in bold type in Table 1.

Prior to analysis, experimental methodology must be considered, to ensure that the bell diameter: weight relationships are not biased by methodological differences. Methods of weight analysis are summarised in 


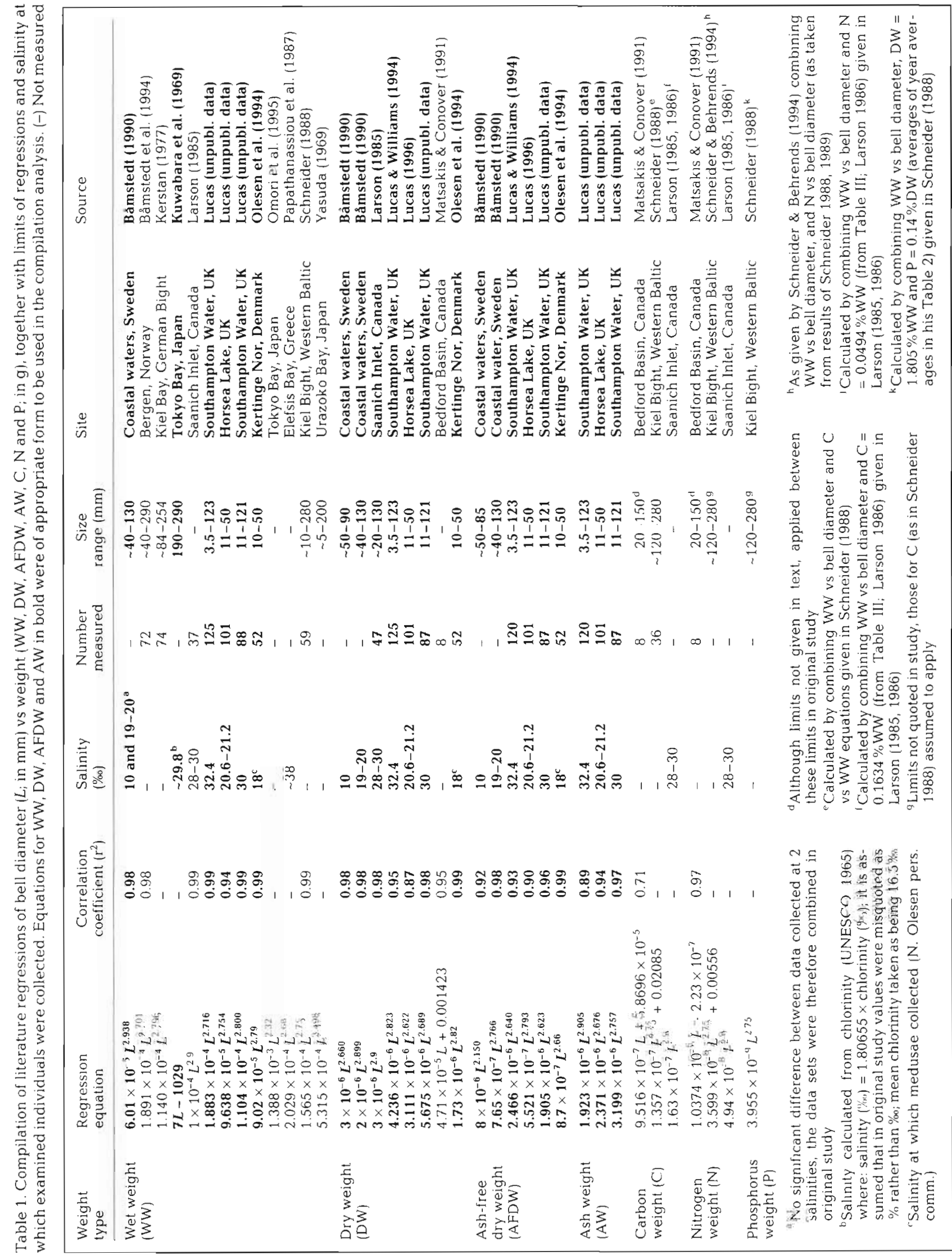


Table 2. In all the studies, initial bell diameters were determined by measuring the full extent of the medusan bell. In the study of Kuwabara et al. (1969) the method of WW determination is not given. However, as the size of individuals are greater than those in all the other studies, as will be seen later, comparisons are not possible in any case. Described methods of WW determination appear to differ only with respect to the blotting method: these differences are likely to have little or no effect on this or the subsequent weight measurements.

Drying methods for DW analysis vary between studies. Methodological differences occur between a first group, i.e. Båmstedt (1990), Lucas (1994, unpubl. data) and Olesen et al. (1994) and a second, i.e. Larson (1986). Evacuation freeze drying was used by Larson (1986), while heat drying was used in the first group of studies. Larson (1986) demonstrated for Aurelia aurita that the freeze-drying method used did not give significantly different results $(p<0.05)$ from those produced by heat drying at $50^{\circ} \mathrm{C}$ for $24 \mathrm{~h}$. As such, DW values are equivalent to those determined by oven drying at temperatures ranging from 50 to $70^{\circ} \mathrm{C}$ (Table 2). Larson (1986) also demonstrated for $A$. aurita that DW measures after drying at $70^{\circ} \mathrm{C}$ were only $\sim 2$ to $3 \%$ less than those at $50^{\circ} \mathrm{C}$. Such differences are minor in comparison to the variations demonstrated later, and may therefore be regarded as of little or no consequence to the conclusions.

In those studies in which AW or AFDW are compared here, ashing was carried out at temperatures varying from 500 to $550^{\circ} \mathrm{C}$. These temperatures were sustained for $24 \mathrm{~h}$ in the studies of Lucas (1994, 1996, unpubl. data) and Lucas \& Williams (1994), but for unspecified periods in the studies of Bamstedt (1990) and Olesen et al. (1994). Ashing at 500 or $550^{\circ} \mathrm{C}$ until constant weight is achieved is unlikely to give significantly different results. Assuming that Bamstedt (1990) and
Olesen et al. (1994) ashed individuals until constant weight was attained, these results are comparable to those after heating for $24 \mathrm{~h}$, a period sufficient to ensure constant weight is achieved (authors' pers. obs.).

Experimental acclimation tests. To further examine the effect of salinity on Aurelia aurita WW, DW, AFDW, and $A W$ individuals were collected from Southampton Water, UK, where salinity was $32 \%$. A total of 53 specimens were gently collected using a plastic container, and immediately transported to the laboratory. They were separated into 2 groups containing individuals ranging in size from 80 to $130 \mathrm{~mm}$, which are present at this time of year. Each group was transferred to 301 buckets containing seawater of either 20 or $32 \%$. The reduced salinity water was made by diluting the $32 \%$ estuarine water collected with distilled water. Salinity was measured in the field and in the laboratory using a portable TS probe. The tanks used to contain the $A$. aurita were kept oxygenated and mixed with an air stone. No food was supplied to either group. After $24 \mathrm{~h}$, the medusae were removed and their bell diameters and WW, DW, AFDW and AW determined using the methods described in Lucas (1994). All individuals appeared healthy and had adjusted their buoyancy (see 'Discussion').

\section{RESULTS}

\section{Compilation and comparisons}

Bell diameter:weight ( $W W, D W, A F D W$ and $A W$ ) relationships are shown in Fig. 1 (and given in bold type in Table 1). The compiled WW, DW, AFDW and AW relationships reveal differences in both the slopes and intercepts. Mean values, standard deviations (SD), coefficients of variation (CV) and ranges (assessed as the [highest value]/[lowest value]) of $a$ and $b$ for the

Table 2. Comparison of methods used in weight quantification of Aurelia aurita in the compiled studies used in salinity analysis Weight methods in bold denote those with relevance to the values used in determination of effects of salinity on body weight (see text for details)

\begin{tabular}{|c|c|c|c|c|}
\hline \multirow[t]{2}{*}{ Source } & \multirow[t]{2}{*}{ Collection } & \multicolumn{3}{|c|}{ Weight method } \\
\hline & & Wet weight & Dry weight & Ash weight \\
\hline Bàmstedt (1990) & $\begin{array}{l}\text { Newly collected } \\
\text { medusae }\end{array}$ & $\begin{array}{l}\text { Blotted with } \\
\text { paper towel }\end{array}$ & $\begin{array}{l}60^{\circ} \mathrm{C} \text { until } \\
\text { constant weight }\end{array}$ & $\begin{array}{l}500^{\circ} \mathrm{C} \text { (time } \\
\text { not given) }\end{array}$ \\
\hline Olesen et al. (1994) & As above & As above & As above & As above \\
\hline $\begin{array}{l}\text { Lucas (1994, } 1996, \\
\text { unpubl. data), Lucas } \\
\& \text { Williams (1994) }\end{array}$ & $\begin{array}{l}\text { Newly collected } \\
\text { medusae }\end{array}$ & $\begin{array}{l}\text { Rinsed with } \\
\text { distilled water } \\
\text { Blotted with paper towel }\end{array}$ & $\begin{array}{l}60 \text { to } 70^{\circ} \mathrm{C} \text { until } \\
\text { constant weight }\end{array}$ & $550^{\circ} \mathrm{C}$ for $24 \mathrm{~h}$ \\
\hline Larson $(1985,1986)$ & $\begin{array}{l}\text { Medusae kept in } \\
\text { filtered seawater }\end{array}$ & $\begin{array}{l}\text { Blotted with } \\
\text { non-absorbant } \\
\text { surface (e.g. } \\
\text { glass or plastic) }\end{array}$ & $\begin{array}{l}30^{\circ} \mathrm{C} \text { for } 1 \text { to } 4 \mathrm{~d} \\
\text { followed by } \\
\text { evacuated freeze } \\
\text { drying for } 1 \text { to } 2 \mathrm{~d}\end{array}$ & $\begin{array}{l}\text { Sub-samples } \\
\text { ground, re-dried in } \\
\text { freeze drier for } 1 \mathrm{~d} \text {, then } \\
\text { ashed at } 450^{\circ} \mathrm{C} \text { for } 4 \mathrm{~h}\end{array}$ \\
\hline
\end{tabular}



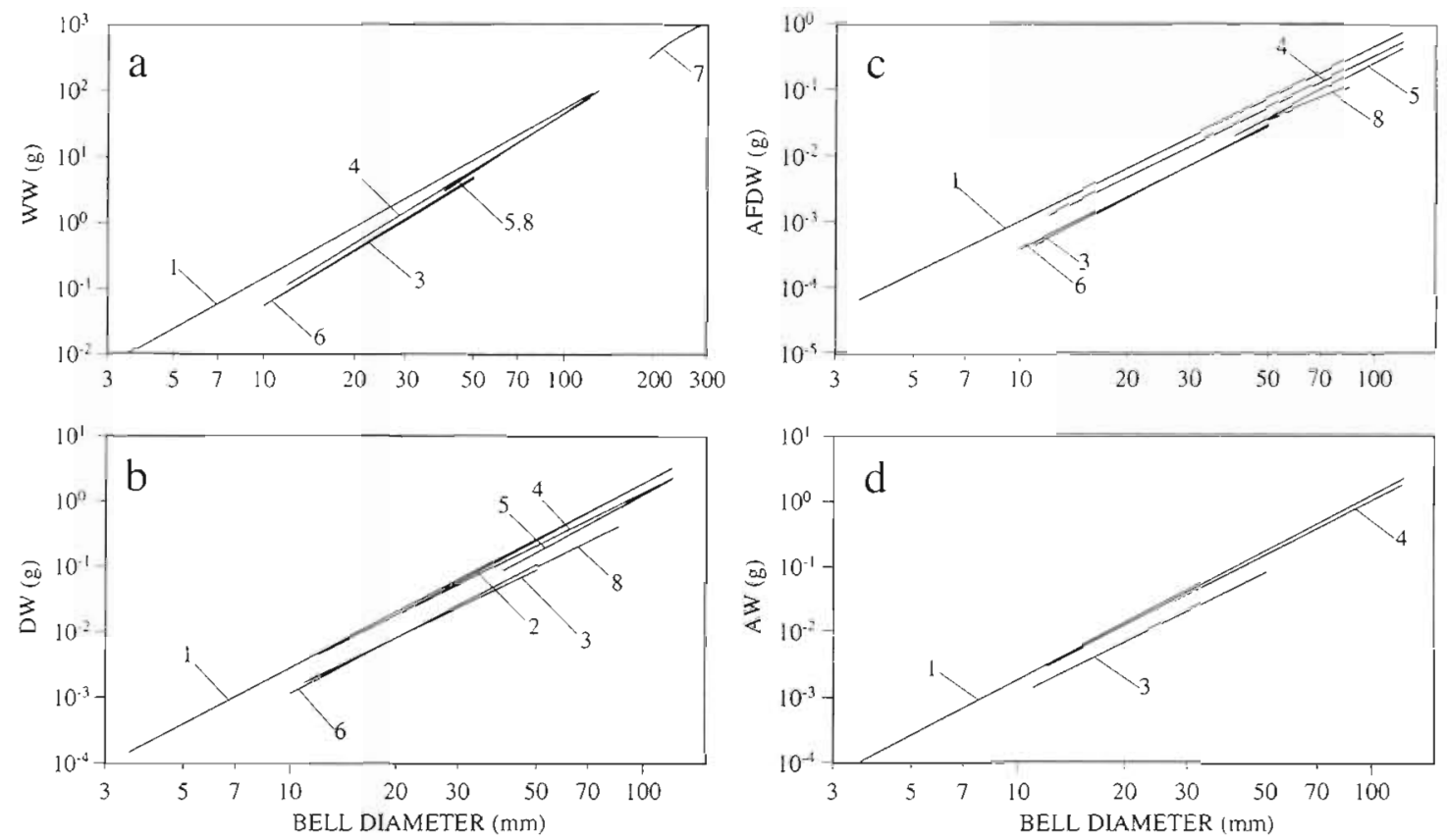

Fig. 1. Aurelia aurita. Bell diameter vs weight relationships for medusae given in studies in which both the salinity at which relationships were determined and approximate ranges were given. Relationships: Bell diameter vs (a) wet weight (WW), (b) dry weight (DW), (c) ash-free dry weight (AFDW), and (d) ash weight (AW). Note scale changes between weight types. Numbered relationships from 1, Lucas (unpubl. data), salinity $32.4 \% ; 2$, Larson (1985), 28 to $30 \%$; 3, Lucas (1996, unpubl. data) 20.6 to $21.2 \%$; 4 , Lucas (unpubl. data), 30\%; 5, Båmstedt (1990), 19 to 20\%; 6, Olesen et al. (1994), 18\%; 7, Kuwabara et al. (1969), $-29 \%$; Båmstedt (1990), 10\%

compiled studies are compared in Table 3. These results demonstrate that the slopes $(b)$ appear rather constant, with the overall range varying between 1.08 and 1.30 -fold. SD values ranged between 0.084 and 0.234 , and CV values from 3.0 to $9.0 \%$. The smallest range $\mathrm{SD}$ and $\mathrm{CV}$ values are for $\mathrm{WW}$, while the largest are for AFDW. Intercepts (a) are far more variable than the slope values, and this is reflected in the ranges, varying between 1.66 - and 14.49-fold, and the CV values, between 25.9 and $116.5 \%$. AW measures have the lowest overall range and $\mathrm{CV}$ at 1.66 -fold and $25.9 \%$ respectively; these figures are derived from fewer regression slopes $(n=3)$ and over a smaller salinity range than in the other studies. WW has the next lowest overall range for the intercept values at 3.13-fold, while AFDW intercepts are the most vari- able with respect to overall range (14.49-fold) and CV $(116.5 \%)$.

Comparisons of the compiled equations (see Table 3) reveals that the WW relationships are the least variable with respect to their slopes, but more variable with respect to intercepts than AW, and of similar variability to DW. However, WW does not vary consistently or significantly with salinity, while the other weight types demonstrated either significant relationships with salinity (i.e. DW and AFDW) or the weight consistently increasing with each increase in salinity even though the relationship is not significant (i.e. $A W)$. Attention should be drawn to the fact that in medusae $>11 \mathrm{~mm}$ bell diameter, the range in predicted wet weights converges (see Fig. 1), while the DW, AFDW and AW values do not. To give an exam-

Table 3. Comparisons of a and $b$ values of the WW, DW, AFDW and AW equations in studies at various salinities. Only those equations converted into the form $W=a L^{b}$ are compared in this table (see text). Mean values, together with standard deviations $(\mathrm{SD})$, coefficients of variation (CV) percentage and ranges (highest values/lowest values), are given for each weight type. $\mathrm{n}$ : number of values available for each comparison

\begin{tabular}{|lccccccc}
\hline Weight type & Salinity range (\%o) & Mean $b$ value (SD, CV) & Range & Mean a value (SD, CV) & Range \\
\hline WW & $10-32.4$ & $2.800(0.084,3.0)$ & 1.08 -fold & $1.091 \times 10^{-4}\left(4.79 \times 10^{-3}, 43.9\right)$ & 3.13 -fold & 5 \\
DW & $10-32.4$ & $2.773(0.115,4.1)$ & 1.11 -fold & $3.25 \times 10^{-6}\left(1.35 \times 10^{-6}, 41.5\right)$ & 3.28 -fold & 7 \\
AFDW & $10-32.4$ & $2.605(0.234,9.0)$ & 1.30 -fold & $2.43 \times 10^{-6}\left(2.83 \times 10^{-6}, 116.5\right)$ & $14.49-$ fold & 6 \\
AW & $20.6-32.4$ & $2.779(0.116,4.2)$ & 1.09 -fold & $2.498 \times 10^{-6}\left(6.47 \times 10^{-7}, 25.9\right)$ & 1.66 -fold & 3 \\
\hline
\end{tabular}


ple, predicted WW values at $11 \mathrm{~mm}$ bell diameter vary by 1.8 -fold $(n=4)$, while DW varies by 2.4 -fold $(\mathrm{n}=4)$, AFDW by $3.1(\mathrm{n}=4)$, and AW by $1.6(\mathrm{n}=3)$. However, at $50 \mathrm{~mm}$ predicted WW values vary by 1.7 fold $(\mathrm{n}=5)$, DW by $3.0(\mathrm{n}=7)$. AFDW by $2.6(\mathrm{n}=6)$, and $A W$ by $2.0(n=3)$.
Fig. 2 shows the predicted weights versus salinity of collection for a variety of bell sizes. The predictions are made from each of the equations given in the original studies, with all applications being within regression limits. The results from weight:salinity regressions are given in Table 4 . WW versus salinity did not show a
Fig. 2. Aurelia aurita. Comparisons of predicted weights (WW, DW, AFDW and AW) of medusae of various bell diameters (11, 20, 40, 50 and $85 \mathrm{~mm}$ ) at various salinities. All bell diameters for which weights are given are within the regression limits of the original studies (see Table 1 and text for explanation)
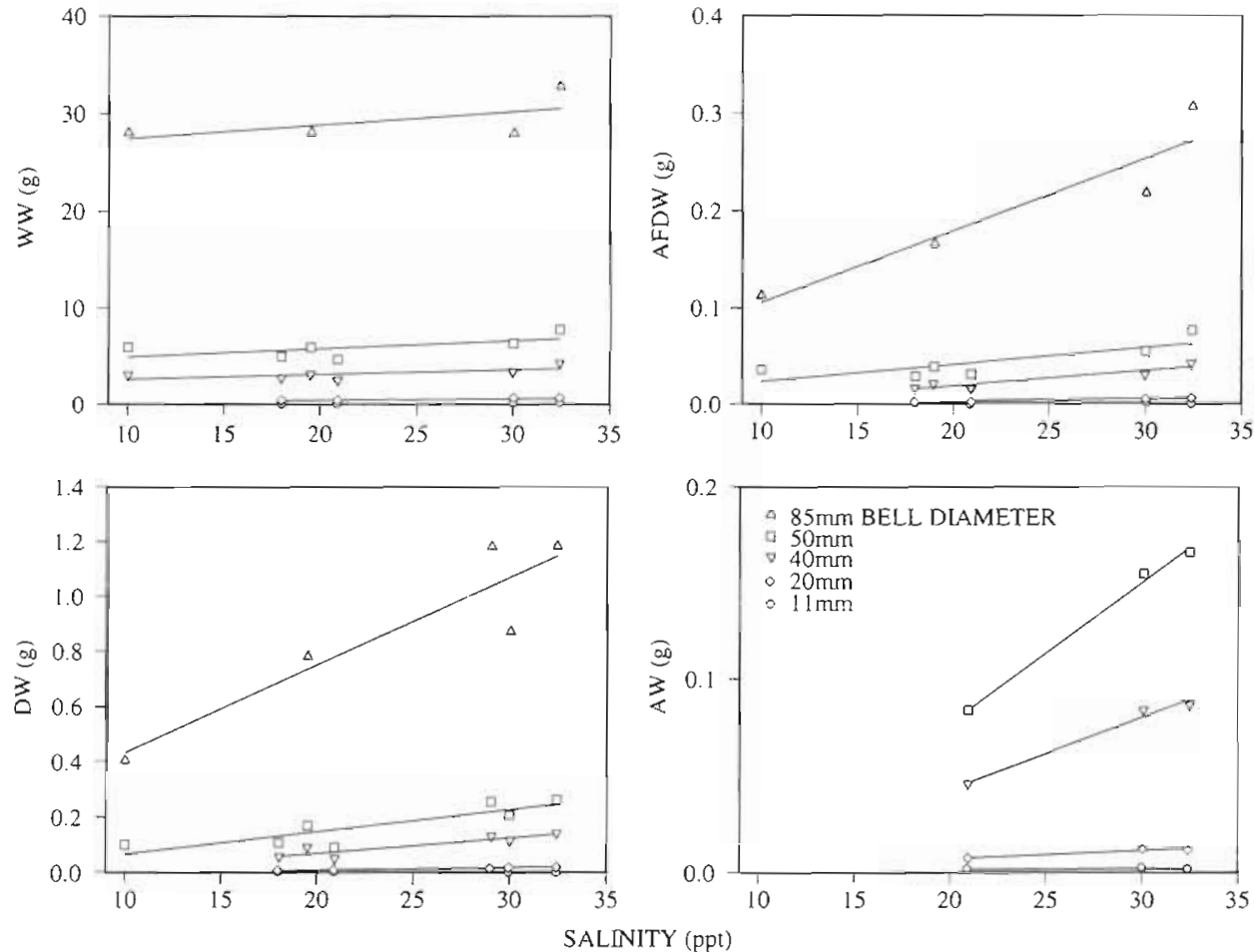

Table 4. Summary of regression results of weight (in g) vs salinity $(S)$ for a variety of bell diameters. Weights calculated from compiled regressions within approximate limits. ns: not significant $(p>0.05)_{i}{ }^{\bullet}$ significant $(p<0.05)$

\begin{tabular}{|c|c|c|c|c|c|c|}
\hline \multirow[t]{2}{*}{ Weight type } & \multirow{2}{*}{$\begin{array}{l}\text { Bell diameter } \\
\text { (mm) }\end{array}$} & \multirow{2}{*}{$\underset{(\%)}{\text { Salinity, }} S$} & \multicolumn{2}{|c|}{ Weight $=a+b S$} & \multirow[t]{2}{*}{$r^{2}$} & \multirow[t]{2}{*}{$\mathrm{p}$} \\
\hline & & & $a$ & $b$ & & \\
\hline \multirow[t]{5}{*}{ WW } & 11 & $18-32.4$ & 0.007 & 0.003 & 0.78 & ns \\
\hline & 20 & $18-32.4$ & 0.057 & 0.016 & 0.81 & ns \\
\hline & 40 & $10-32.4$ & 2.052 & 0.050 & 0.46 & ns \\
\hline & 50 & $10-32.4$ & 4.115 & 0.082 & 0.37 & ns \\
\hline & 85 & $10-32.4$ & 26.024 & 0.137 & 0.35 & ns \\
\hline \multirow[t]{5}{*}{ DW } & 11 & $18-32.4$ & $-1.663 \times 10^{-3}$ & $1.687 \times 10^{-4}$ & 0.98 & - \\
\hline & 20 & $18-32.4$ & -0.010 & $9.154 \times 10^{-4}$ & 0.97 & $\cdot$ \\
\hline & 40 & $18-32.4$ & -0.044 & 0.006 & 0.82 & - \\
\hline & 50 & $10-32.4$ & -0.013 & 0.008 & 0.75 & . \\
\hline & 85 & $10-32.4$ & 0.115 & 0.032 & 0.85 & $\cdot$ \\
\hline \multirow[t]{5}{*}{ AFDW } & 11 & $18-32.4$ & $-7.037 \times 10^{-4}$ & $6.106 \times 10^{-5}$ & 0.91 & $\cdot$ \\
\hline & 20 & $18-32.4$ & -0.003 & $2.865 \times 10^{-4}$ & 0.92 & $\cdot$ \\
\hline & 40 & $18-32.4$ & -0.013 & $1.591 \times 10^{-3}$ & 0.90 & $\cdot$ \\
\hline & 50 & $10-32.4$ & 0.006 & $1.758 \times 10^{-3}$ & 0.66 & $\cdot$ \\
\hline & 85 & $18-32.4$ & 0.029 & 0.007 & 0.88 & ns \\
\hline \multirow[t]{4}{*}{$A W$} & 11 & $20.9-32.4$ & $1.491 \times 10^{-4}$ & $6.506 \times 1.0^{-5}$ & 0.71 & ns \\
\hline & 20 & $20.9-32.4$ & $-1.654 \times 10^{-3}$ & $4.331 \times 10^{-4}$ & 0.89 & $\mathrm{~ns}$ \\
\hline & 40 & $20.9-32.4$ & -0.031 & 0.004 & 0.98 & ns \\
\hline & 50 & $20.9-32.4$ & -0.069 & 0.007 & 1.0 & \\
\hline
\end{tabular}


relationship significantly different from zero for any of the tested bell diameters ( $p>0.05$ ). For DW, all 5 sizes tested, i.e. 11, 22, 40, 50 and $85 \mathrm{~mm}$ bell diameters, show significant increases with salinity, and all except $85 \mathrm{~mm}$ show significant increases with salinity for AFDW ( $p<0.05)$. The predictions for AW only show significant relationships when bell diameter is $50 \mathrm{~mm}$, and, although the other sizes are not significant, the results show consistent increases in AW with increasing salinity. The lack of significance may simply be a result of there being relatively few data (only 3 points) for these regressions. AW appears to approximately double as salinity increases by $\sim 10 \%$.

\section{Experimental acclimation tests}

Fig. 3 shows the relationships that describe WW, DW, AFDW and AW at a salinity of $32 \%$, and at $20 \%$ after $24 \mathrm{~h}$ of acclimation. ANCOVA comparisons for each of the weight types supports the visual differences; the slopes are not significantly different $(p<0.05)$, while the intercepts are significantly different for DW, AFDW and AW $(p<0.0005)$, but not for WW $(p>0.05)$.

\section{DISCUSSION}

The analyses of compiled regressions of DW and AFDW versus bell diameter demonstrate that the dif- ferences between values appear to be dependent upon salinity at collection (see Fig. 2, Table 4). There were consistent increases in the AW values with increasing salinity. However, although the regression was only significant $(p<0.05)$ in one case, the AW data consisted of fewer points than the other weight types; more data may help in demonstrating the underlying relationship. There was no significant correlation between WW and salinity, and no consistent increase in the WW values for a medusa of given size with increasing salinity. The variability between the slope values and the overall range in weight for a given size are also lower for WW than the other weight values.

The results from the compiled study are supported by the experimental acclimation study. While DW, AFDW and AW as a function of bell diameter changed significantly over the $24 \mathrm{~h}$ acclimation period, WW values did not. Båmstedt (1990) reported finding no significant difference between the bell diameter:WW relationship for individuals collected from water with salinities of 10 and $19-20 \%$. DW and AFDW were significantly different however, weights increasing as salinity increased.

The results of the compiled regressions (Table 4) show that, in absolute terms, DW and AFDW increase more rapidly with increasing salinity for larger individuals than for small. For example, DW of an $85 \mathrm{~mm}$ individual is $0.461 \mathrm{~g}$ greater at $32.4 \%$ than it is at $18 \%$, whereas DW of an $11 \mathrm{~mm}$ individual is only $0.00243 \mathrm{~g}$ larger at $32.4 \%$ than it is at $18 \%$. However, in relative
Fig. 3. Aurelia aurita. Comparisons of bell diameter to WW, DW, AFDW and AW relationships for medusae at $32 \%$ (dashed lines and solid circles) with relationships at $20 \%$ after acclimation for $24 \mathrm{~h}$ (solid lines and empty circles). $95 \%$ confidence limits for each relationship are given
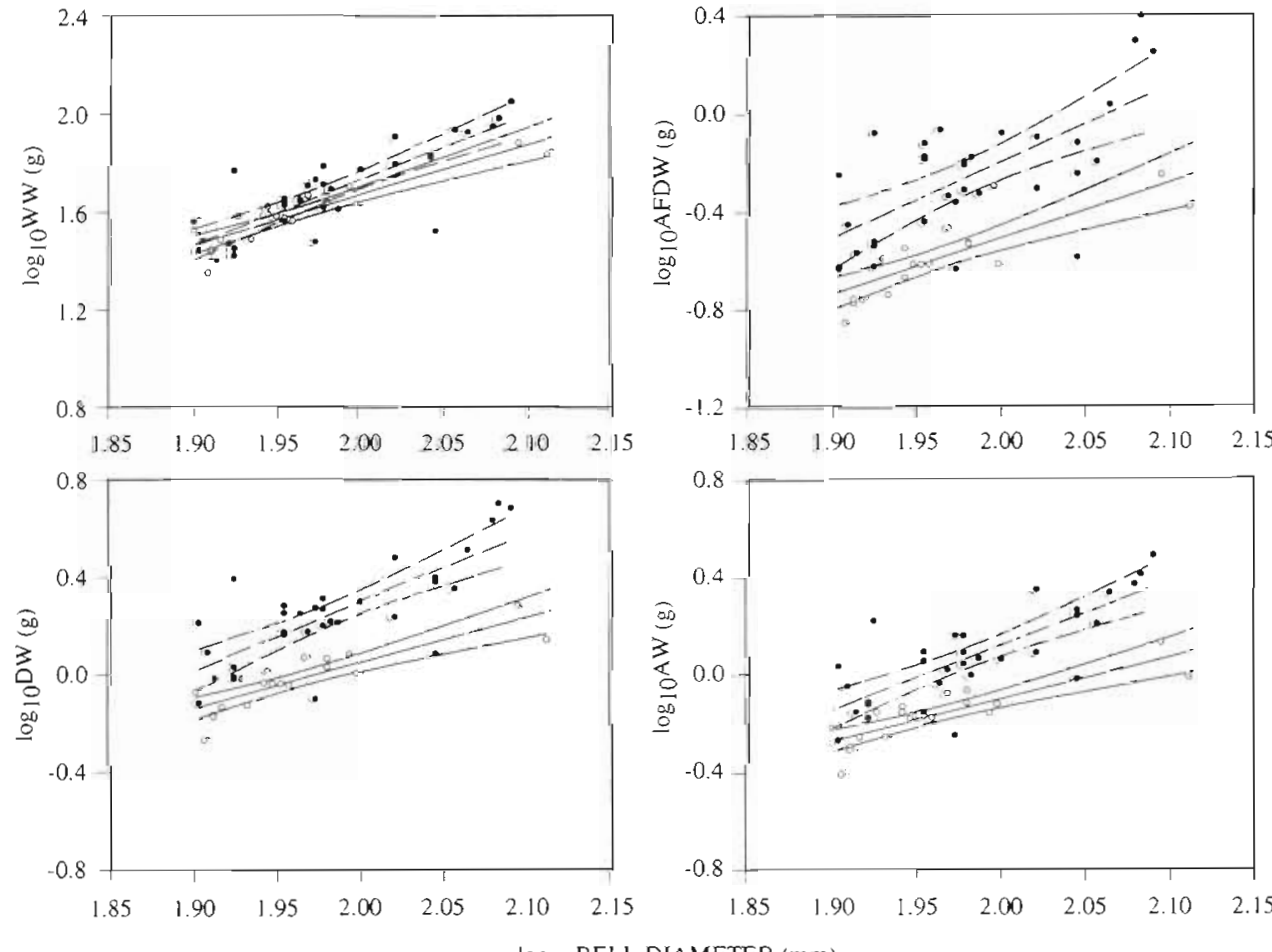
terms (i.e. as percentage change in body weight per \% increase in salinity) the pattern is more complex. For AFDW the relative increases are less for larger individuals than smaller ones. The pattern is less clear for DW, although there is a general increase with increasing size. The results suggest that, in relative terms, inorganic changes in tissue composition as a function of salinity are greater in larger individuals. Relative changes in water of hydration (assessed from the changes in AFDW) would, however, appear to be greatest in the smaller individuals. This indicates that there may be no simple relationship between inorganic content and water of hydration.

The acclimation study shows that DW, AFDW and AW decrease when Aurelia aurita are placed in water of a lower salinity. Changes in DW and AFDW are probably the result of changes in the non-organic components of the medusae. This would seem justified, given that changes were measured relative to the weight of a control group of incubated $A$. aurita; no obvious mucus excretions were observed during the incubations. This increase in the non-organic component consists of a measured change in AW, and additionally an inferred change in water of hydration. The only investigations that have demonstrated these rapid changes in body weight as a result of salinity changes were completed by Larson (1985) on the hydromedusa Aequorea victoria and by Wright \& Purcell (1997) on the scyphomedusa Chrysaora quinquecirrha. In the study of Larson (1985) individuals were collected from $30.8 \%$ and kept in water of salinity $24.5,30.8$ and $34.5 \%$. WW, DW and AW were determined after a $24 \mathrm{~h}$ acclimation period. Larson's results suggest that over this salinity range of $10 \%$, DW increased from $\sim 3.4$ to $-4.5 \%$ of $W W$. For an $85 \mathrm{~mm} A$. aurita medusa it can be estimated from the equations established here (Table 4 ), that a $10 \%$ increase in salinity (20 to $30 \%$ ) will lead to an increase in DW\%WW from 2.6 to $3.6 \%$, i.e. an increase in DW of $1.0 \%$ of WW. For an $11 \mathrm{~mm}$ medusae the increase in DW is $1.1 \%$ of WW over the same $10 \%$ increase in salinity. The results for a hydromedusa and a scyphomedusa would therefore appear similar between these 2 investigations. It was not indicated whether AW increased significantly with salinity in the acclimation study of Larson (1985). In the present acclimation experiments AW increased significantly with increasing salinity, whilst in the compilation study, although only one of the regressions was significant (see Table 4), there were consistent increases in this weight with salinity. In the study of Wright \& Purcell (1997) only WW changes were examined, and, in contrast to our results, large increases in the WW of individuals transferred from water of salinity 16 to $8 \%$ were observed after a $24 \mathrm{~h}$ period. The increases in weight over control individuals being of the order $30 \%$. We have no explanation for such contrasting results between their and our investigations, except species-specific differences; this area obviously needs attention in the future.

Our results suggest that water of hydration as a percentage of DW will increase with increasing salinity. If it is assumed that the increase in AFDW between the lowest and the highest salinity in the compilation study (Fig. 1, Table 4) is the result of changes in the amount of hydrated water, then one can estimate the minimum water of hydration at the higher salinities. The regression equations from the compilation study (Table 4) predict that AFDW of an $85 \mathrm{~mm}$ bell diameter medusae at $18 \%$ is $0.155 \mathrm{~g}$, while at $32.4 \%$ it is $0.256 \mathrm{~g}$. Water of hydration at $32.4 \%$ in this case would be a minimum of $\sim 40 \%$ of the AFDW and $\sim 9 \%$ of the DW. Completing the same calculation for a $10 \mathrm{~mm}$ bell diameter medusae gives a water of hydration minimum of $\sim 69 \%$ of the AFDW and $-23 \%$ of the DW These minimum values are in close agreement with the value of Larson (1986), who demonstrated using the $\mathrm{H}$-surplus method of Madin et al. (1981) that Aurelia aurita (of unspecified size) collected at 28 to $30 \%$ had water of hydration which was $55.7 \%$ of the AFDW and $11.7 \%$ of the DW. Our values would suggest that water of hydration as percentage of both AFDW and DW decreases with increasing bell diameter

When Aurelia aurita are placed in water of lower salinity than previously acclimated, they sink to below their previously maintained depth, while individuals placed in higher salinity float (authors' pers, obs.). Their buoyancy is subsequently adjusted over the following few hours so that their vertical position is similar to that previously maintained. Such buoyancy changes as a result of rapid change in environmental salinity occur in other scyphomedusae and hydromedusae, ctenophores and siphonophores (Jacobs 1937, Mills 1984, Wright \& Purcell 1997). Potential strategies for allowing gelatinous organisms to maintain their buoyancy, and to vary it rapidly, include selective exclusion of heavy ions with a large negative partial molal volume. Sulphate exclusion coupled with an isosmotic replacement with chloride ions occurs in most gelatinous species examined, including $A$. aurita (Robertson 1949, Bidigare \& Biggs 1980), although other ions such as $\mathrm{Ca}^{2+}$ and $\mathrm{Mg}^{2+}$ may also play a role.

DW and AFDW measurements of Aurelia aurita have been converted to elemental units such as carbon using literature ratios without apparent regard for salinity (e.g. van der Veer \& Oorthuysen 1985, Olesen et al. 1994, Lucas 1996). This may lead to error, however, and it is illuminating to take some of these studies as examples. Olesen et al. (1994) and Lucas (1996) both applied the conversion factors of Schneider (1988), where $1 \mathrm{mg} \mathrm{DW}=0.051 \mathrm{mg} C$ for medusae $<20 \mathrm{~mm}$ 
and $0.0701 \mathrm{mg} \mathrm{C}$ for medusae $>20$ to $50 \mathrm{~mm}$. However, as a result of salinity differences Olesen et al. (1994) gave DW values $\sim 60 \%$ lower than those of Lucas (1996), and will have therefore estimated carbon weight to be $-60 \%$ lower too

There have been 3 studies which allow some form of derivation of carbon and nitrogen of Aurelia aurita medusae as a function of bell diameter, and 1 for phosphorus. These are the studies of of Larson (1986), Schneider (1988) and Matsakis \& Conover (1991), and their results are given in Table 1 and shown in Fig. 4. These comparisons show that the results of Matsakis \& Conover (1991) differ dramatically from those of the other 2 studies. The DW equation of Matsakis \& Conover (1991) also gives very much lower weight predictions than in the other studies. As the discrepancies are unaccountably large, we believe their relationships should be discounted.

As water of hydration changes with size, and whole body carbon and nitrogen as a percentage of DW also change with size (Schneider 1988), it is advisable to apply regressions of measured elemental weights versus bell diameter. Using single ratios of elemental weight to AFDW, DW or WW for different sized individuals will lead to error as these changes will not be considered. The bell diameter:carbon regression constructed from the results of Schneider (1988) does take into account changes in size, while that produced from Larson's $(1985,1986)$ results assumes that C\%WW and N\%WW are both constant with size, with the single values being applied to WW regressions. The regressions for nitrogen determined in Schneider \& Behrends (1994) has been constructed to take account of this size effect. Additional relationships can be derived by combining the size-specific $\mathrm{C} \% \mathrm{DW}$ and $\mathrm{N} \% \mathrm{DW}$ values with the DW regression produced by Schneider (1988) (see Table 5). There is no regression for phosphorus which takes variation with size into account. It may be
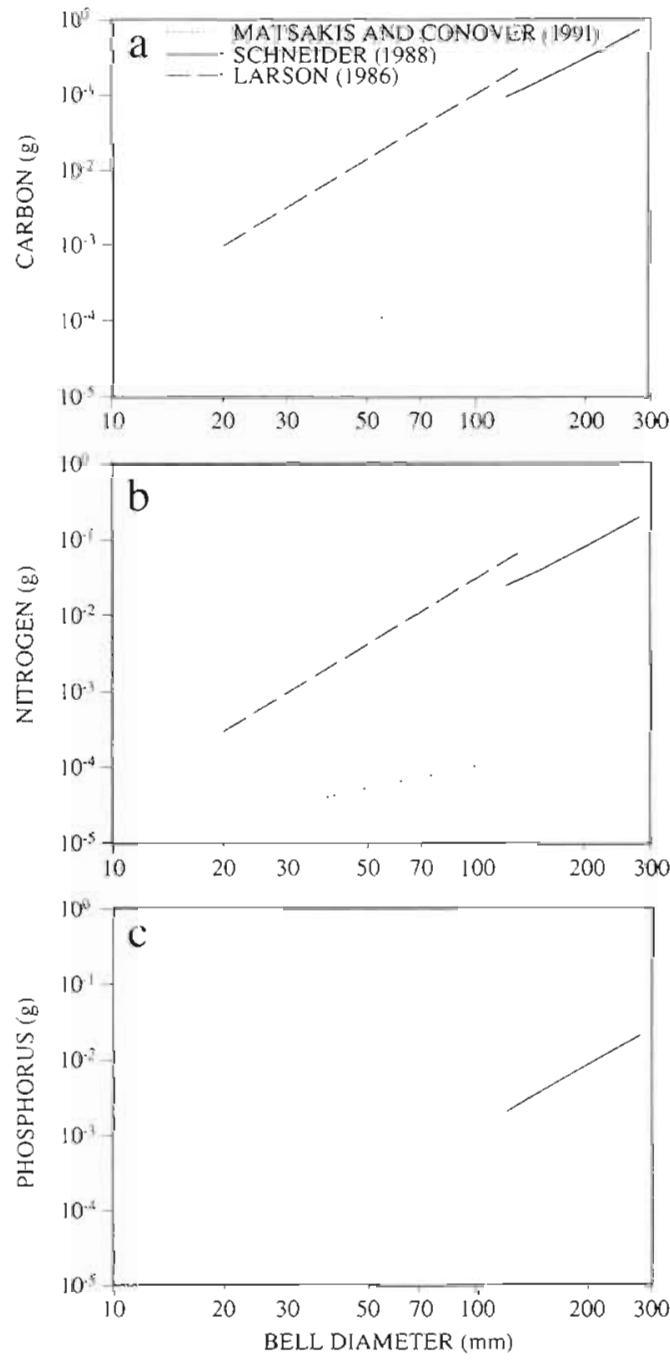

Fig. 4. Aurelia aurita. Comparisons of elemental relationships described in the literature. Relationships: bell diameters vs (a) carbon weight, (b) nitrogen weight and (c) phosphorus weight. The relationships given by Matsakis \& Conover (1991) appear to be erroneous (see text for details)

Table 5. Aurelia aurita. Measurements of carbon (C), nitrogen (N) and phosphorus (P) as a percentage of dry weight (DW) for $A$. aurita of various sizes and developmental stages. All sizes given are bell diameters except for planulae, for which total body lengths are quoted. n: Number of determinations. The results of Matsakis \& Conover (1991) are excluded as these appear to be erroneous

\begin{tabular}{|c|c|c|c|c|c|c|c|}
\hline & Salinity $(\%)$ & Size (mm) & $\mathrm{C} \% \mathrm{DW}(\mathrm{n})$ & $\mathrm{N} \% \mathrm{DW}(\mathrm{n})$ & $\mathrm{P} \% \mathrm{DW}(\mathrm{n})$ & Collection site & Source \\
\hline Planulae & Not specified & 0.255 & $39(6)$ & $8.7(6)$ & & Kiel Fjord, Baltic & $\begin{array}{l}\text { Schneider \& } \\
\text { Weisse (1985) }\end{array}$ \\
\hline Medusae & Not specified & $\begin{array}{l}<20 \\
20-50 \\
120-140 \\
200-220 \\
270-310 \\
>20(1982 \text { year average) } \\
>20 \text { (1983 year average) }\end{array}$ & $\begin{array}{l}7.01(6) \\
5.14(6) \\
5.42(6) \\
4.88(4) \\
4.76(5) \\
5.21(19) \\
5.11(17)\end{array}$ & $\begin{array}{l}1.92(6) \\
1.40(6) \\
1.38(6) \\
1.28(4) \\
1.31(5) \\
1.36(19) \\
1.40(17)\end{array}$ & $0.14(7)$ & Kiel Bay, Baltic & Schneider (1988) \\
\hline & $28-30$ & Not specified & $4.3(6)$ & $1.3(6)$ & & $\begin{array}{l}\text { Saanich Inlet, } \\
\text { Canada }\end{array}$ & $\begin{array}{l}\text { Larson } \\
(1985,1986)\end{array}$ \\
\hline
\end{tabular}


difficult to apply some of the elemental regressions to all areas as sizes may fall outside the regression limits. Additionally, the size at maturation and fertility status varies dramatically for Aurelia durita between locations and seasonally (see Hirst 1996, Lucas 1996), and thus elemental and biochemical compositions will also vary. Carbon, nitrogen and phosphorus measures as percentages of DW for different sizes of $A$. aurita are summarised in Table 5, and the data compiled highlight some of the large errors that may occur if single ratios were applied without due regard to size. Further bell diameter:elemental weight measurements are obviously urgently needed to allow future accurate assessments of elemental weights and where material budgeting is undertaken.

It is recommended in studies where non-elemental weights of gelatinous zooplankton are quantified that the salinity of water from which individuals were collected be quoted and that this should be considered when incubating and holding gelatinous zooplankton ex situ. Not only do gelatinous zooplankton occur over a very broad range of salinities, but single species in single study areas, or between areas, may also be present over large salinity ranges [e.g. the ctenophore Mnemiopsis leidyi at 3.4 to $20 \%$ (Miller 1974) and the scyphozoans Phyllorhiza punctata at 10 to $35 \%$ (García 1990) and Chrysaora quinquecirrha at 5 to $25 \%$ (Wright \& Purcell 1997)]. Similar findings to the effect of salinity on quantification given here for Aurelia aurita may occur in other true gelatinous organisms, including other scyphomedusae, as well as hydromedusae and ctenophorans, given the previous descriptions of weight and buoyancy changes with salinity in these groups. Indeed, differences between DW and carbon and nitrogen contents as a percentage of DW in the ctenophore $M$. leidyi have already been attributed to differences in the salinity of the environments from which the sample individuals were taken (Nemazie et al. 1993). The variations in body weight resulting from different surrounding salinities highlighted in this paper need to be considered in studies in which the body weights of gelatinous organisms found at varying salinities are utilised. Not allowing for corrections when these are appropriate may result in large errors. We recommend that body size to elemental weight regressions be applied directly. When DW or AFDW are utilised, subsequent conversions to elemental terms, ratios determined at the same salinity or allowances for salinity should be made. Workers failing to take these precautions may produce results which are highly inaccurate.

Acknowledgements. A.G.H. was supported by a NERC studentship, number GT/4/92/261/A.

\section{LITERATURE CITED}

Alldredge AL (1984) The quantitative significance of gelatinous zooplankton as pelagic consumers. In: Fasham MJR (ed) Energy of materials in marine ecosystems: theory and practice. Plenum Press, New York, p 407-433

Bamstedt U (1.990) Trophodynamics of the scyphomedusae Aurelia aurita. Predation rate in relation to abundance, size and type of prey organism. J Plankton Res 12:215-229

Båmstedt U, Martinussen MB, Matsakis S (1994) Trophodynamics of the two scyphozoan jellyfishes, Aurelia aurita and Cyanea capillata, in western Norway. ICES J Mar Sci 51:369-382

Bidigare RT, Biggs DC (1980) The role of sulfate exclusion in buoyancy maintenance by siphonophores and other oceanic gelatinous zooplankton. Comp Biochem Physiol $66: 467-471$

Conover RJ (1979) Secondary production as an ecological phenomenon. In: Van der Spoel S, Pierrot-Bults AC (eds) Zoogeography and diversity of plankton. Arnold, New York, p 50-86

Fraser JH (1969) Experimental feeding of some medusae and chaetognaths. J Fish Res Bd Can 26:1743-1762

García JR (1990) Population dynamics and production of Phyllorhiza punctata (Cnidaria: Scyphozoa) in Laguna Joyuda, Puerto Rico. Mar Ecol Prog Ser 64:243-251

Hamner WM, Jenssen RM (1974) Growth, degrowth and irreversible cell difterentiation in Aurelia aurita. Am Zool 14: $833-849$

Hirst AG (1996) Zooplankton production and energy flowtowards a biological model of Southampton Water PhD thesis, University of Southampton

Huntley ME, Hobson LA (1978) Medusa predation and phytoplankton dynamics in a temperate fjord, British Columbia. J Fish Res Bd Can 35:257-261

Hyman LH (1938) The water content of medusae. Science 87: $166-167$

Hyman LH (1940) The Invertebrata. Protozoa through Ctenophora. McGraw-Hill, New York

Hyman LH (1943) Water content of medusae. Nature 151:140

Jacobs E (1937) Beobachtungen über das Scheben der Siphonophoren. Z Vgl Physiol 24:583-601

Kerstan M (1977) Untersuchungen zur Nahrungsökologie von Aurelia aurita. Diplomarbeit, Kiel University (in German)

Kramp PL (1961) Synopsis of the medusae of the World. J Mar Biol Assoc UK 40:1-469

Kuwabara R, Sato S, Noguchi N (1969) Ecological studies of the medusae Aurelia aurita. I. Distribution in NorthEastern Tokyo Bay in Summer 1966 and 1967. Bull Jpn Soc Sci Fish 35:156-162. Translation no. 1944, Department of Agriculture and Fisheries for Scotland, Marine Laboratory, Aberdeen

Larson RJ (1985) Trophic ecology of gelatinous predators (Cnidaria and Ctenophora) in Saanich Inlet, Vancouver Island, British Columbia, Canada. PhD thesis, University of Victoria

Larson RJ (1986) Water content, organic content, and carbon and nitrogen composition of medusae from the Northeast Pacific. J Exp Mar Biol Ecol 99:107-120

Lucas CH (1994) Biochemical composition of Aurelia aurita in relation to age and sexual maturity. J Exp Mar Biol Ecol 183:179-192

Lucas $\mathrm{CH}$ (1996) Population dynamics of Aurelia aurita (Scyphozoa) from an isolated brackish lake, with particular reference to sexual reproduction. J Plankton Res 18:987-1007

Lucas CH, Williams JA (1994) Population dynamics of the 
scyphomedusa Aurelia aurita in Southampton Water. J Plankton Res 16:879-895

Lucas CH. Williams JA (1995) Gelatinous predators and their potential impact on the mesozooplankton community of Southampton Water. In: Eleftheriou A, Ansell AD, Smith CJ (eds) Proc 28th Eur Mar Biol Symp, Crete, Greece, 1993. Olsen and Olsen, Fredensborg, p 73-78

Madin LP, Cetta CM, McAlister VL (1981) Elemental and biochemical composition of salps (Tunicata: Thaliacea). Mar Biol 63:217-226

Matsakis S, Conover RJ (1991) Abundance and feeding of medusae and their potential impact as predators on other zooplankton in Bedford Basin (Nova Scotia, Canada) during spring. Can J Fish Aquat Sci 48:1419-1430

Miller RJ (1974) Distribution and biomass of an estuarine ctenophore population. Mnemiopsis leidyi, (A. Agassiz). Chesapeake Sci 15:1-8

Mills CE (1984) Density is altered in hydromedusae and ctenophores in response to changes in salinity. Biol Bull (Woods Hole) 166:206-215

Möller H (1979) Significance of coelenterates in relation to other plankton organisms. Ber Dtsch Wiss Komm Meeresforsch 27:1-18

Möller H (1980) A summer survey of large zooplankton, particularly scyphomedusae, in North Sea and Baltic. Meeresforschung 28:61-68

Nemazie DA, Purcell JE, Glibert PM (1993) Ammonium excretion by gelatinous zooplankton and their contribution to the ammonium requirements of microplankton in Chesapeake Bay. Mar Biol 116:451-458

Odum EP (1971) Fundamentals of ecology, 3rd edn. WB Saunders Company, Philadelphia

Olesen NJ, Frandsen K, Riisgård HU (1994) Population dynamics, growth and energetics of jellyfish Aurelia aurita in a shallow fjord. Mar Ecol Prog Ser 105:9-18

Omori M, Ikeda T (1984) Methods in marine zooplankton ecology. John Wiley and Sons, New York

Omori M, Ishii H, Fujinaga A (1995) Life history strategy of Aurelia aurita (Cnidaria, Scyphomedusae) and its impact

Editorial responsibility: Jennifer Purcell (Contributing Editor), Cambridge, Maryland, USA on the zooplankton communsty of Tokyo Bay. ICES J Mar Sci 52:597-603

Papathanassiou E, Panayotidis P, Anagnostaki K (1987) Notes on the biology and ecology of the jellyfish Aurelia aurita Lam. in Elefsis Bay (Saronikos Gulf, Greece). PSZN I: Mar Ecol 8:49-58

Reeve MR, Baker LD (1975) Production of two planktonic carnivores (Chaetognath and Ctenophore) in South Florida inshore waters. Fish Bull US 73:238-248

Robertson JD (1949) Ionic regulation in some marine invertebrates. J Exp Biol 26:182-200

Schneider G (1988) Chemische Zusammensetzung und Biomasseparameter der Ohrenqualle Aurelia aurita. Helgol Meeresunters 42:319-327

Schneider G (1989) The common jellyfish Aurelia aurita: standing stock, excretion and nutrient regeneration in the Kiel Bight, western Baltic. Mar Biol 100:507-514

Schneider G, Behrends G (1994) Population dynamics and the trophic role of Aurelia aurita medusae in Kiel Bight and western Baltic. ICES J Mar Sci 51:359-367

Schneider G, Weisse T (1985) Metabolism measurements of Aurelia aurita planulae larvae, and calculations of maximal survival period of the free swimming stage. Helgol Meeresunters 39:43-47

UNESCO (1965) First report of the joint panel on oceanographic tables and standards. Tech Pap Mar Sci No. 1

van der Veer HW, Oorthuysen W (1985) Abundance, growth and food demand of the scyphomedusa Aurelia aurita in the western Wadden Sea. Neth J Sea Res 19:38-44

Vinogradov AP (1953) The elementary chemical composition of marine organisms. Mem Sears Found Mar Res 2: $194-219$

Wright DA, Purcell JE (1997) Effect of salinity on ionic shifts in mesohaline scyphomedusae, Chrysaora quinquecirrha. Biol Bull (Woods Hole) 192:332-339

Yasuda T (1971) Ecological studies on the jelly-fish Aurelia aurita in Urazoko Bay, Fukui Pref. II. Monthly change in the bell-length composition and breeding season. Bull Jpn Soc Sci Fish 7:364-370

Submitted: October 10, 1997, Accepted: January 5, 1998 Proofs received from author(s): April 24, 1998 